\title{
Wahania warunków klimatycznych jako katalizator zmiany społecznej w społeczeństwach historycznych ${ }^{*}$
}

\author{
Adam Izdebski \\ https://orcid.org/0000-0002-3456-5478 \\ Instytut Historii Uniwersytetu Jagiellońskiego, Max Planck Institute for the Science of Human History
}

Zarys treści: Wahania warunków klimatycznych w przeszłości, charakteryzujące się różną skalą przestrzenną i czasową, oddziaływały na społeczeństwa poddane różnorodnym presjom ekologicznym, gospodarczym, politycznym i kulturowym. $\mathrm{Z}$ tego względu nie należy traktować klimatu jako izolowanego czynnika bezpośrednio wywołującego określone skutki dziejowe, lecz raczej jako jednego z aktorów w złożonej sieci społeczno-przyrodniczej. Przyjmując ten punkt widzenia, należy stwierdzić, że rola wahań warunków klimatycznych w dziejach sprowadza się raczej do katalizowania zmian społecznych bądź ich modyfikowania, nie jest zaś główną siłą sprawczą. Niniejszy artykuł ilustruje ten problem wybranymi przykładami z historii świata śródziemnomorskiego w starożytności i średniowieczu.

Słowa kluczowe: zmiany klimatu, historia środowiskowa, przemiany społeczne, sprawczość, rezyliencja, kryzys

\section{Wprowadzenie}

Chociaż lektura doniesień popularnonaukowych w europejskich i amerykańskich gazetach może sprawiać wrażenie, że zmiany klimatu w przeszłości miały decydujący wpływ na dzieje człowieka, w rzeczywistości były to zjawiska znacznie bardziej skomplikowane i rola klimatu w dziejach pozostaje tematem kontrowersyjnym. Dość powiedzieć, że wśród historyków trwa spór między tymi, którzy chcieliby $\mathrm{w}$ różnie rozumianych zmianach klimatu widzieć podstawową przyczynę upadku Cesarstwa Rzymskiego w późnym antyku

\footnotetext{
* Niniejsza publikacja przygotowana została w ramach projektu Narodowego Programu Rozwoju Humanistyki „W poszukiwaniu transdyscyplinarnej synergii: przełomy gospodarcze Polski z perspektywy historyczno-przyrodniczej na tle europejskim", realizowanego na Uniwersytecie w Białymstoku w latach 2016-2019.
}

Abstract: Impacts of climatic changes on the course of history do not occur along simple trajectories. Past climatic fluctuations occurred at different temporal and spatial scales, while at the same time the societies that experienced them were undergoing parallel ecological, economic, political and cultural pressures. For this reason, it is not legitimate to treat climate as the only isolated agent of societal change, but it should rather be regarded as one of several historical factors in a complex natural-social network. In this way, climatic changes are rightly seen as catalysts of societal change or factors that modify their scale, scope, or direction, rather than the main causative agent, coming from the external world. The article discusses this theoretical challenge using a number of examples from the ancient and medieval Mediterranean.

Keywords: climate change, environmental history, societal change, agency, resilience, crisis

czy załamania się potęgi Imperium Osmańskiego na początku XVII w., a innymi badaczami, którzy uważają klimat za jeden z wielu czynników mających znaczenie dla wystąpienia tych zjawisk historycznych, i to niekoniecznie fundamentalny ${ }^{1}$.

\footnotetext{
${ }^{1}$ Tezę o kluczowej roli klimatu w upadku Cesarstwa Rzymskiego zaproponował Kyle Harper: K. Harper, The fate of Rome. Climate, disease, and the end of an empire, Princeton 2017. Głosy sceptyczne zob. J. Haldon i in., Plagues, climate change, and the end of an empire. A response to Kyle Harper's "The fate of Rome” (1). Climate, „History Compass", 16 (12), 2018, e12508; ciż, Plagues, climate change, and the end of an empire. A response to Kyle Harper's "The fate of Rome” (2). Plagues and a crisis of empire, „History Compass”, 16 (12), 2018, e12506; ciż, Plagues, climate change, and the end of an empire. A response to Kyle Harper's "The fate of Rome" (3). Disease, agency, and collapse, „History Compass”, 16 (12), 2018, e12507. W odniesieniu do Imperium Osmańskiego na kluczową rolę klimatu wskazuje Sam White: S. White, The climate of rebellion in the early modern Ottoman Empire, Cambridge 2011. Pogląd bardziej sceptyczny zob. 0. Özel, The collapse of rural order in Ottoman Anatolia. Amasya 1576-1643, Leiden 2016 (Ottoman Empire and its Heritage, 61).
} 
W niniejszym artykule zajmę się wybranym aspektem tej debaty, a mianowicie postrzeganiem wahań warunków klimatycznych jako katalizatora zmiany społecznej. Terminu wahania warunków klimatycznych, a nie zmiany klimatu używam tutaj nieprzypadkowo. Po pierwsze, pragnę podkreślić w ten sposób, że zmienność klimatu, którą można obserwować dzięki źródłom pisanym i rekonstrukcjom paleoklimatycznych dla ostatnich kilku tysięcy lat (a zatem odkąd istnieją rozwinięte społeczeństwa historyczne), w żadnym razie nie może być porównana ze współczesną zmianą klimatu, czyli gwałtowną destabilizacją ziemskiego systemu klimatycznego, której doświadczamy w tej chwili² ${ }^{2}$ Po drugie, posługuję się tym ogólnym pojęciem, aby wskazać na fakt, że gdy historycy mówią o zmianach klimatu, mogą mieć na myśli bardzo różne zjawiska, o różnej skali czasowej i przestrzennej ${ }^{3}$. Z jednej strony występowały pojedyncze wydarzenia, ekstremalne zjawiska pogodowe trwające od kilku godzin do kilku miesięcy, z drugiej jednak obserwowano całe dekady i półwiecza, podczas których warunki termiczne czy opadowe odbiegały w odczuwalny dla ludzi sposób od wcześniejszego, podobnie długiego okresu. W niniejszym tekście przyjrzę się przykładom obu zjawisk, aby pokazać szeroki wachlarz mechanizmów, przez które klimat może stawać się istotnym aktorem $\mathrm{w}$ procesie dziejowym.

Pytanie, które sobie tutaj stawiam, dotyczy społecznego kosztu przystosowania się konkretnych społeczeństw historycznych do wahań warunków klimatycznych ${ }^{4}$. Ponieważ społeczności ludzkie istnieją jako

\footnotetext{
Szerzej na temat tego problemu, z bogatym wyborem literatury przyrodniczej i filozoficznej: E. Bińczyk, Epoka człowieka. Retoryka i marazm antropocenu, Warszawa 2018. Zob. także: M. Popkiewicz, A. Kardaś, S. Malinowski, Nauka o klimacie, Katowice 2018.

${ }^{3}$ Więcej na ten temat zob. A. Izdebski, Średniowieczni Rzymianie i przyroda. Interdyscyplinarna historia środowiskowa, Kraków 2018, s. 55-68.

${ }^{4} 0$ pojęciu społecznego kosztu rezyliencji (odporności) i przystosowania do zmian warunków przyrodniczych (fizycznych), które są kluczowe dla istnienia społeczeństw historycznych zob. A. Izdebski, L. Mordechai, S. White, The social burden of resilience. A historical perspective, „Human Ecology”, 46, 2018, s. 291-303.
}

część złożonych systemów społeczno-przyrodniczych, które podlegają równocześnie dynamice zjawisk fizycznych (takich jak klimat) oraz społeczno-kulturowych (takich jak konflikty zbrojne, przemiany religijne itp.), to nawet krótkotrwała zmiana któregoś z istotnych warunków przyrodniczego istnienia ludzkich społeczności zazwyczaj wymaga podjęcia wysiłku przystosowania się do niej ${ }^{5}$. Oznacza to konieczność modyfikacji struktur ekologicznych, gospodarczych i społecznych, które mają swoją własną dynamikę zmian i rozwoju. Pewne grupy społeczne uzyskują w rezultacie szerszy niż dotychczas dostęp do zasobów, polepszają swoją sytuację gospodarczą albo podnoszą pozycję społeczną, podczas gdy inne znajdują się w gorszej sytuacji i tracą na znaczeniu. Nawet jeśli społeczeństwo jako całość odnosi sukces, radzi sobie z wahaniami warunków klimatycznych, czyli nadal istnieje, zachowując ciagłość własnych instytucji, struktur społeczno-gospodarczych itp., to jednak ponosi pewien koszt tego przystosowania się. Koszt ten, co ważne, nie rozkłada się po równo między poszczególnymi grupami tworzącymi to społeczeństwo. Innymi słowy, oznacza to, że wahania warunków klimatycznych nie oddziaływają w izolacji od pozostałych procesów społecznych i przyrodniczych, którym w danym momencie historycznym podlega konkretne społeczeństwo, lecz raczej wpisują się w złożoną matrycę zastanej dynamiki procesów społeczno-przyrodniczych i kulturowych. Dołączając do niej, niejako z zewnątrz, klimat wpływa na szybkość oraz natężenie tych procesów i staje się katalizatorem zmiany społecznej. W dalszej części artykułu, posługując się wybranymi przykładami z dziejów świata śródziemnomorskiego w okresie starożytności i średniowiecza, postaram się bardziej szczegółowo omówić to interesujące zjawisko.

\footnotetext{
${ }^{5}$ Pojęcie systemu społeczno-przyrodniczego omawiam szerzej w: A. Izdebski, Średniowieczni Rzymianie, s. 11-15, 77-79.
} 


\section{Rola społeczno-gospodarcza miasta i wsi w późnym antyku}

Być może najciekawszy przypadek utraty pozycji przez jedną grupę społeczną w momencie, gdy można mówić o zwieńczonym sukcesem przystosowaniu się do zmiany klimatu przez społeczeństwo jako całość, zaobserwowano w ostatnich stuleciach późnej starożytności. Ludność Cesarstwa Wschodniorzymskiego zdołała bowiem wykorzystać możliwości, jakie stworzył dla rolnictwa wzrost przeciętnej ilości opadów w okresie zimowym (czyli w porze roku kluczowej dla uprawy zbóż), który nastąpił w latach ok. $470-700$ po $\mathrm{Chr}^{6}$ Zwiększona wilgotność klimatu Anatolii i Lewantu stworzyła nowe warunki rozwoju dla rolnictwa i wsi, w szczególności zaś umożliwiła ekspansję rolnictwa na tereny półpustynne bądź wcześniej zbyt suche, aby uprawiać na nich zboża. Powiązane z tymi procesami zmiany gospodarcze doprowadziły ostatecznie do istotnego przekształcenia struktur społeczeństwa wschodniorzymskiego.

Badania powierzchniowe prowadzone przez archeologów w różnych częściach wschodniego basenu Morza Śródziemnego pozwoliły zidentyfikować znaczną ilość materiału świadczącą o ekspansji osadnictwa wiejskiego na nowe tereny bądź o jego intensyfikacji na terenach wcześniej już zasiedlonych. Mamy do czynienia z wielką liczbą znalezisk ceramicznych bądź wręcz istniejącymi do dziś ruinami wsi zbudowanych w późnej starożytności (IV-VI w. po Chr. ${ }^{7}$. Co więcej, w wielu miejscach znajdujemy także archeologiczne bądź przyrodnicze świadectwa specjalizowania się lokalnego rolnictwa w określonym typie upraw, które pozwalały na stosunkowo łatwy udział w wymianie handlowej w ramach wschodniorzymskiego systemu

${ }^{6}$ A. Izdebski i in., The environmental, archaeological and historical evidence for regional climatic changes and their societal impacts in the Eastern Mediterranean in Late Antiquity, „Quaternary Science Reviews", 136, 2016, s. 189-208.

${ }^{7}$ Szczegółowe zestawienie badań archeologicznych zob. tamże. gospodarczego. Są to takie produkty rolne, jak oliwa czy wino. Wsie, a nawet całe obszary zajmujące się niemal wyłącznie ich produkcją można znaleźć w różnych częściach Cesarstwa Wschodniorzymskiego ${ }^{8}$. Rzecz jasna, nie jest tak, że rozkwit rolnictwa nastąpił wyłącznie z powodu wzrostu ilości opadów w okresie zimowym. W niektórych miejscach - zwłaszcza w Grecji i na Sycylii - jest on nawet poświadczony dla okresu wcześniejszego, poprzedzającego tę zmianę warunków klimatycznych? Za podstawowe przyczyny tego zjawiska gospodarczego należy uznać założenie nowej stolicy Cesarstwa - Konstantynopola, a zatem stworzenie gigantycznego rynku dla produktów rolnych, wspieranego przez samo państwo oraz stabilizację polityczną i finansową wschodniej części świata śródziemnomorskiego. Oczywiście sprzyjające określonemu typowi rolnictwa warunki klimatyczne musiały wpłynąć na skalę ekspansji gospodarki wiejskiej. Widać to szczególnie w fakcie, że rolnictwo i osadnictwo wiejskie wkroczyło z ogromną siłą na tereny, które w innych warunkach klimatycznych po prostu się do tego nie nadawaty albo przynajmniej nie gwarantowałyby wystarczająco wysokich plonów ${ }^{10}$.

Wahania warunków klimatycznych stały się zatem bez wątpienia katalizatorem zmiany społecznej o tyle, o ile wzmocniły dynamikę procesów sprzyjających ekspansji gospodarczej. Wpływ klimatu

\footnotetext{
${ }^{8}$ Odnośnie do Anatolii zob. np.: G. Varinlioğlu, Trade, craft and agricultural production in town and countryside in southeastern Isauria, $\mathrm{w}$ : Archaeology and the cities of Asia Minor in Late Antiquity, ed. 0. Dally, C. Ratté, Ann Arbor, Mich 2011 (Kelsey Museum Publication, 6), s. 151-171; A. Izdebski, The economic expansion of the Anatolian countryside in Late Antiquity. The coast versus inland regions, „Late Antique Archaeology", 10, 2013, s. 343-376; tenże, Byzantine Miletus. Environmental history of the hinterland, „Archäologischer Anzeiger”, 2, 2016, s. 270-280.

${ }^{9}$ E. Weiberg in., The socio-environmental history of the Peloponnese during the Holocene. Towards an integrated understanding of the past, "Quaternary Science Reviews", 136, 2016, s. 40-65; L. Sadori i in., Climate, environment and society in southern Italy during the last 2000 years. A review of the environmental, historical and archaeological evidence, „Quaternary Science Reviews”, 136, 2016, s. 173-188.

${ }^{10} \mathrm{~A}$. Izdebski, Średniowieczni Rzymianie, s. 165-175.
} 
sięgał jednak głębiej i miał także związek z bardzo ważnymi przemianami strukturalnymi, które zachodziły w społeczeństwie wschodniorzymskim pod koniec starożytności. Procesy bogacenia się wsi i jej ekspansji terytorialnej, wzmocnione przez sprzyjający klimat, miały istotne znaczenie dla zmiany politycznego, instytucjonalnego i gospodarczego znaczenia społeczności miejskich i wiejskich (miast i wsi) w ramach późnego Cesarstwa Rzymskiego. Oznaczało to zerwanie z dominacją miast, charakterystyczną dla tej części świata od czasów hellenistycznych. Osady wiejskie budowane w ramach późnoantycznej intensyfikacji rolniczej bardzo wyraźnie odróżniały się ładem przestrzennym od tych, które powstawały wcześniej. Gospodarstwa nie były rozrzucone, ale wyraźnie zgrupowane, miały swój środek ciężkości (kościół), a dodatkowo bardzo często na poszczególnych budynkach mieszkalnych i gospodarczych widniały elementy dekoracyjne, świadczące o ambicjach i zasobności ich użytkowników. Można by wręcz powiedzieć, że powstały wtedy wsie nieustępujące znacząco rozmiarem i skalą architektoniczną małym miastom ${ }^{11}$. Co więcej, zwłaszcza w przypadku nowej kolonizacji, wsie takie powstawały w dużej odległości od wcześniejszych miast hellenistycznych i rzymskich, a ich miejsce w siatce osadniczej wskazywałoby na dużą samodzielność gospodarczą ${ }^{12}$.

W toczącej się od niemal półwiecza debacie na temat upadku miast w późnoantycznych Anatolii i Lewancie (mimo trwania późnorzymskich struktur gospodarczych i politycznych) coraz wyraźniej podkreśla się, że proces ten staje się w pełni widoczny $\mathrm{w}$ materiale archeologicznym z przełomu VI i VII w. ${ }^{13}$ Dodatkowo w VII

\footnotetext{
${ }^{11}$ G. Dagron, Entre village et cité. La bourgade rurale des IV-VIIe siècles en Orient, „Koinonia”, 3, 1979, s. 29-52.

${ }^{12}$ P. Niewöhner, Aizanoi and Anatolia. Town and countryside in late Late Antiquity, „Millenium. Jahrbuch zu Kultur und Geschichte des ersten Jahrtausends n. Chr.", 3, 2006, s. 239-253.

${ }^{13}$ C. Foss, Archaeology and the „Twenty cities” of Byzantine Asia, „American Journal of Archaeology”, 81 (4), 1977, s. 469-486; P. Niewöhner,
}

stuleciu ciężar rzymskiego systemu podatkowego ostatecznie przenosi się z miast do wsi, będących już podstawowymi jednostkami poboru podatków ${ }^{14}$. Na początku VII w. wzmocniona przez wahania klimatu ekspansja wsi trwała już od co najmniej kilku dziesięcioleci, wyraźnie zmieniając siatkę osadniczą i podział zasobów między miastem a wsią. Nie oznacza to jednak, że przyczyną tych procesów były wahania klimatu - można je też wyjaśnić, wskazując na dobrze rozpoznane czynniki gospodarcze i polityczne. Sprzyjający klimat umożliwił jednak rozwój i bogacenie się wsi w takim zakresie, jaki musiał istotnie przyspieszyć, jeśli nie wręcz przypieczętować, zmianę społeczno-gospodarczej roli miast i wsi pod koniec starożytności.

\section{Sroga zima i „wielki głód” w Bizancjum w X w.}

Wiek X w dziejach Bizancjum jest stosunkowo dobrze udokumentowany. Dysponujemy licznymi źródłami prawnymi, hagiograficznymi i historiograficznymi pochodzącymi z tego okresu. Wszystkie zawierają informacje o srogiej zimie na przełomie lat 927/928 po Chr., która miała doprowadzić do potężnego głodu w 928 r. Wedle źródeł mróz trwał wówczas nieprzerwanie przez sto dwadzieścia dni, aż do kwietnia, co doprowadziło do bardzo niskich zbiorów zbóż. Nietypowe warunki atmosferyczne i ich społeczne skutki miały wystąpić w Anatolii i prawdopodobnie także północnej Grecji ${ }^{15}$. Co ciekawe, dane paleoklimatyczne (analizy nacieków jaskiniowych oraz osadów jeziornych z Anatolii) nie sugerują, by zima 927/928 r. trwała szczególnie długo i odznaczała się

Urbanism, w: The archaeology of Byzantine Anatolia. From the end of Late Antiquity until the coming of the Turks, ed. P. Niewöhner, Oxford 2017, s. 39-59 (https://www.academia.edu/36208255/Urbanism, dostęp: 19 listopada 2019).

${ }^{14}$ W. Brandes, J. Haldon, Towns, tax and transformation: state, cities and their hinterlands in the East Roman World, C. 500-800, w: Towns and their territories between late antiquity and the early Middle Ages, ed. G.P. Brogiolo, N. Gauthier, N. Christie, Leiden 2000 (Transformation of the Roman World, 9), s. 141-172.

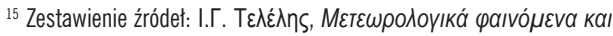

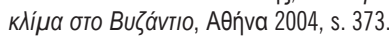


wyjątkowo dużą pokrywą śnieżną, podczas gdy te same dane wyraźnie wskazują na wystąpienie srogiej zimy w roku 939, co wedle wszelkiego prawdopodobieństwa miało związek z wybuchem wulkanu na Islandii ${ }^{16}$. Jest zatem prawdopodobne, że o ile zima 927 r. rzeczywiście spowodowała niższe zbiory w roku kolejnym, to jednak jej ekstremalną srogość i ogromny zasięg (w tym symboliczne sto dwadzieścia dni mrozu) należy uznać za element kreacji źródeł literackich (Żywotu Eukasza Stylity oraz Kroniki Logotety ${ }^{17}$ ), powstałych co najmniej dwadzieścia, trzydzieści lat po opisywanych wydarzeniach.

O ile jednak można podać w wątpliwość wyjątkowość tej zimy w skali bezwzględnej (co nie oznacza, że nie mogła być trudna w skali ludzkiego doświadczenia), to nie ulega wątpliwości, że głód, który nasze źródła z nią wiążą, musiał być dotkliwy. Jest on wymieniony nie tylko przez źródła narracyjne, ale także w tekstach prawnych, m.in. wydanej w 934 r. noweli cesarza Romana Lekapena, której celem było zaradzenie społecznym skutkom „wielkiego głodu"18. W preambule do noweli cesarz wyjaśnia, że celem jego działań było zaradzenie sytuacji, w której potężni (gr. dynatoi) zyskują na krzywdzie słabych (ptochoi). Innym słowy, cesarz chciał zaradzić pogorszeniu się sytuacji niższych warstw społeczeństwa w stosunku do elit

\footnotetext{
${ }^{16}$ Dane paleoklimatyczne: 0.M. Göktürk i in., Climate on the southern Black Sea coast during the Holocene. Implications from the Sofular Cave record, "Quaternary Science Reviews", 30 (19-20), 2011, s. 2433-2445; M.D. Jones i in., A high-resolution late Holocene lake isotope record from Turkey and links to North Atlantic and monsoon climate, „Geology”, 34, 2006, s. 361-364. Zima roku 939 w Europie: C. Oppenheimer i in., The Eldgjá eruption. Timing, long-range impacts and influence on the Christianisation of Iceland, „Climatic Change”, 147 (3-4), 2018, s. 369-381. Szczegółowe omówienie aspektów paleoklimatycznych zimy roku 927: A. Izdebski, L. Mordechai, S. White, The social burden, s. 291-303.

${ }^{17}$ H. Delehaye, Les Saints stylites, Bruxelles 1923 (Subsidia Hagiographica, 14), s. 205; S. Wahlgren, Symeonis Magistri et Logothetae Chronicon, Berlin 2006, s. 330.

${ }^{18}$ Wydanie krytyczne noweli można znaleźć w: N. Svoronos, Les Novelles des empereurs macedoniens concernant la terre et les stratiotes, Athènes 1994. Szczegótowa analiza: M. Kaplan, Les hommes et la terre à Byzance du $\mathrm{Vl}^{*}$ au X $\ell^{e}$ siècle. Propriété et exploitation du sol, Paris 1992, s. 414-426.
}

polityczno-gospodarczych. W szczególności jego celem było powstrzymanie procesu skupowania ziemi ubogich rolników przez bogatych urzędników państwowych i innych przedstawicieli elit cesarstwa ${ }^{19}$. Źródła łączą zatem srogą zimę i związany z nią głód ze zmianą społeczną. Dzięki bizantyjskiemu systemowi wypłacania urzędnikom i dowódcom wynagrodzenia w złotej monecie elity zdobywały kapitał pieniężny, który mogły przeznaczyć na wykup ziemi i akumulację wielkich majątków. To nie sroga zima stworzyła więc tę sytuację i zapoczątkowała głęboką zmianę społeczną, która niepokoiła władze cesarskie. Jej wystąpienie w ramach określonej konfiguracji czynników gospodarczych i politycznych musiało jednak przyspieszyć proces umacniania materialnej przewagi elit nad niższymi warstwami społeczeństwa.

\section{Późnośredniowieczne ochłodzenia i islamizacja Anatolii}

Mniej oczywisty przykład podobnego mechanizmu - przechylania szali równowagi społeczno-gospodarczej przez ekstremalne zjawiska pogodowe na korzyść określonej grupy społecznej - pochodzi z późnośredniowiecznej Anatolii. Począwszy od połowy XI w., ta bizantyjska część świata śródziemnomorskiego, ostoja Cesarstwa Wschodniorzymskiego w okresie najazdów arabskich, poddawana była coraz silniejszej presji migracyjnej turkmeńskich nomadów i grup wojskowych, w przeważającej mierze wyznających islam. W XII w. w centrum Anatolii swoje państwo stworzyli muzułmańscy Seldżucy, podczas gdy kontrolę nad zachodnimi regionami, bliżej Morza Egejskiego, aż do lat sześćdziesiątych XIII w. zachowali głównie Bizantyjczycy (z ośrodkiem władzy w Konstantynopolu, a po 1204 r. w Nicei). Utrata panowania nad tymi terenami przez elity bizantyjskie i ich postępująca kulturowa islamizacja

\footnotetext{
${ }^{19} \mathrm{R}$. Morris, The powerful and the poor in tenth-century Byzantium. Law and reality, „Past and Present”, 73, 1976, s. 3-27.
} 
zaskakująco zbiegły się z kilkuletnim gwałtownym ochłodzeniem (dotyczącym przede wszystkim okresu wiosenno-letniego), które nastąpiło na półkuli północnej po wybuchu ogromnego indonezyjskiego wulkanu Samalas w 1257 r. $^{20}$

Choć pozornie wahania warunków klimatycznych powinny mieć podobnie korzystny lub niekorzystny wpływ na życie wszystkich społeczności zamieszkujących ten sam obszar, nie jest to wcale oczywiste, ponieważ związki poszczególnych grup społecznych i etnicznych ze środowiskiem przyrodniczym mają bardzo różny charakter ${ }^{21}$. Taka różnorodność była też charakterystyczna dla południowo-zachodniej Anatolii w XIII stuleciu. Greckojęzyczna ludność zajmowała się rolnictwem, w tym przede wszystkim uprawą winorośli i oliwek, podczas gdy mieszkańcy turkmeńscy trudnili się seminomadycznym pasterstwem ${ }^{22}$. Nisze ekologiczne tych dwóch grup społecznych były więc różne, co szczególnie dobrze widać w bardzo silnie zróżnicowanej topografii górzystej zachodniej Anatolii, poprzecinanej żyznymi dolinami rzecznymi. Bizantyjczycy zależeli zatem od położonych w dolinach agroekosystemów sadów i pól uprawnych, natomiast turkmeńscy pasterze, chociaż wracali w niżej położone partie dolin w okresie zimowym, korzystali także z gór, a ich zwierzęta karmiły się roślinami mniej wrażliwymi na niższe temperatury

\footnotetext{
${ }^{20}$ F. Lavigne $\mathrm{i}$ in., Source of the great A.D. 1257 mystery eruption unveiled, Samalas volcano, Rinjani Volcanic Complex, Indonesia, „Proceedings of the National Academy of Sciences”, 110 (42), 2013 , S. 16742-16747; S. Guillet i in., Climate response to the Samalas volcanic eruption in 1257 revealed by proxy records, „Nature Geoscience", 10 (2), 2017, s. 123-128. Na temat prawdopodobnego wystąpienia w tym okresie ochłodzenia wulkanicznego w zachodnie Anatolii zob. E. Xoplaki i in., The Medieval climate anomaly and Byzantium. A review of the evidence on climatic fluctuations, economic performance and societal change, "Quaternary Science Reviews", 136,2016, s. 229-252.

${ }^{21}$ Także dziś to samo gorące i suche lato w $2018 \mathrm{r}$. w Niemczech bardziej zaszkodziło rolnikom niż mieszkańcom miast; było też np. bardziej dotkliwe dla hodowców bydła niż dla rolników, których głównym zajęciem jest uprawa zbóż.

${ }^{22} \mathrm{P}$. Thonemann, The Maeander Valley. A historical geography from antiquity to Byzantium, Cambridge 2011; A. Izdebski, Byzantine Miletus, s. 270-280.
}

lata i częstsze przymrozki niż oliwki czy winorośl. W związku z tym chłodniejsze lata związane z wulkaniczną zimą, która nastąpiła po wybuchu Samalasa, bardziej osłabiły przyrodnicze podstawy gospodarczej i politycznej pozycji ludności greckiej na terenach południowo-zachodniej Anatolii, i to właśnie wtedy, kiedy elity bizantyjskie skoncentrowały swoją uwagę i zasoby militarne na zdobyciu i utrzymaniu Konstantynopola (odbitego z rąk łacinników w 1261 r.). Częściowo tłumaczy to łatwość, z jaką turkmeńskie elity ustanowiły własne organizmy państwowe na tych terenach w drugiej połowie XIII w.

Co ciekawe, wulkaniczna zima w okresach letnich na przełomie lat pięćdziesiątych i sześćdziesiątych XIII w. wydaje się początkiem dłuższego procesu zmian społeczno-przyrodniczych w zachodniej Anatolii, a mianowicie zanikania bizantyjskiego rolnictwa, z jego doniosłą rolą uprawy oliwek i winorośli. Chociaż zmiany te musiały mieć przede wszystkim podłoże polityczne i kulturowe, to jednak wpływały na nie również długotrwałe wahania warunków klimatycznych, bardzo dobrze rozpoznane dla okresu późnego średniowiecza. W odniesieniu do Anatolii mamy dwie rekonstrukcje dendroklimatyczne z tego okresu, które pozwalają na odtworzenie warunków pogodowych w porze późnej wiosny. Dowiadujemy się z nich, że w latach 1400-1450 bardzo często wysteppowały tam chłodne wiosny, a w latach 1434-1503 większość wiosen odznaczała się opadami znacznie poniżej przeciętnej ${ }^{23}$. Opady i temperatury wiosny i wczesnego lata mają kluczowe znaczenie dla zbioru oliwek i winogron, co oznacza, że pod koniec średniowiecza obie te bizantyjskie uprawy stały się mniej przewidywalne i mniej opłacalne. Przyrodnicze podstawy

\footnotetext{
${ }^{23} \mathrm{R}$. Touchan i in., May-June precipitation reconstruction of south-western Anatolia, Turkey during the last 900 years from tree rings, „Quaternary Research”, 68 (2), 2007, s. 196-202; I. Heinrich i in., Winter-to-spring temperature dynamics in Turkey derived from tree rings since AD 1125, „Clim Dyn”, 41, 2013, s. 1685-1701.
} 
bizantyjskiego sposobu życia uległy w rezultacie dalszemu, bardziej długotrwałemu zachwianiu, co zresztą widać $\mathrm{w}$ danych pyłkowych, które wskazują na malejący udział tych upraw w krajobrazie omawianego regionu ${ }^{24}$.

\section{Podsumowanie}

Powyższe przykłady pokazują, że niezależnie, czy mówimy o pojedynczej srogiej zimie, czy też o długoterminowych zmianach warunków klimatycznych, i niezależnie, czy postrzegamy te zmiany jako korzystne bądź nie, poprawna ocena ich wpływu na dzieje jest zadaniem złożonym. O ile można myśleć o wahaniach warunków klimatycznych w okresie przednowoczesnym (bo przecież nie dziś, w antropocenie!) jako o czynniku egzogenicznym w stosunku to systemu społeczno-przyrodniczego, jako o swoistym Deus ex machina teatru dziejów, to jednak zewnętrzność tego czynnika w stosunku do dynamiki zmian społecznych i ekologicznych nie oznacza, że przebija on siłą wszystkie pozostałe uwarunkowania wpływające na kierunek procesu historycznego. Nie jest to klucz do naszej przeszłości, ale raczej rodzaj stresora bądź czynnika modyfikującego przyrodnicze warunki funkcjonowania społeczeństw. Zasięg jego ewentualnego wpływu zależy od całości struktur ekologicznych, gospodarczych i politycznych w danym momencie rozwoju konkretnego społeczeństwa.

\section{Bibliografia}

The archaeology of Byzantine Anatolia. From the end of Late Antiquity until the coming of the Turks, ed. P. Niewöhner, Oxford 2017.

Bińczyk E., Epoka cztowieka. Retoryka i marazm antropocenu, Warszawa 2018.

Brandes W., Haldon J., Towns, tax and transformation. State, cities and their hinterlands in the East Roman World, C. 500-800, w: Towns and their territories

\footnotetext{
${ }^{24}$ A. Izdebski, G. Koloch, T. Słoczyński, Exploring Byzantine and Ottoman economic history with the use of palynological data. A quantitative approach, „Jahrbuch der österreichischen Byzantinistik”, 65, 2015, s. 67-110; A. Izdebski, Byzantine Miletus, s. 270-280.
}

Powyższe przykłady pokazują także, że nie do końca można mówić o jednoznacznie pozytywnej bądź negatywnej zmianie klimatu. Tak samo jak nie jest oczywiste, czy trwanie potężnych, scentralizowanych państw jest sukcesem ludzkości, czy raczej przyczyną ludzkiego nieszczęścia ${ }^{25}$, tak i zmiana klimatu może mieć bilans dodani dla jednej grupy, a dla innej stać się przyczyną wielkiego nieszczęścia. Choć wydawać by się mogło, że w tej drugiej sytuacji znajdowały się zazwyczaj warstwy niższe i kulturowo upośledzone, to przytoczone przykłady celowo mają podawać tę prawidłowość w wątpliwość. Na zmianach klimatu w późnoantycznej Anatolii i Lewancie nie skorzystali mieszkańcy miast, dziedzice hellenistyczno-rzymskiej cywilizacji, ale stosunkowo odległe od klasycznej kultury grecko-rzymskiej społeczności wiejskie. W późnośredniowiecznej Anatolii z ochłodzeniem klimatu lepiej radzili sobie nie osiadli na tych terenach od wieków greccy rolnicy, lecz raczej turkmeńscy półnomadowie. Jeśli istnieje jeden postulat metodologiczny ważny dla społecznej historii klimatu niezależnie od epoki, którą się zajmujemy, to jest nim otwarcie na nieoczywistość związków klimatu i społeczeństwa oraz na paradoksalne uwikłanie klimatu jako siły fizycznej, całkowicie zewnętrznej od ludzkiego działania, w gęstą sieć społeczno-przyrodniczych zależności. between late antiquity and the early Middle Ages, ed. G.P. Brogiolo, N. Gauthier, N. Christie, Leiden 2000 (Transformation of the Roman World, 9), s. 141-172.

Dagron G., Entre village et cité. La bourgade rurale des IVVII siècles en Orient, „Koinonia”, 3, 1979, s. 29-52.

Delehaye H., Les Saints stylites, Bruxelles 1923 (Subsidia Hagiographica, 14).

\footnotetext{
${ }^{25}$ Zob. fascynujące studium filozoficzno-historyczne dotyczące najwcześniejszych systemów państwowych: J.C. Scott, Against the grain. A deep history of the earliest states, New Haven 2017.
} 
Foss C., Archaeology and the "Twenty cities” of Byzantine Asia, „American Journal of Archaeology”, 81 (4), 1977, s. 469-486.

Göktürk O.M., Fleitmann D., BadertscherS., Cheng H., Edwards R.L., Leuenberger M., Fankhauser A., Tüysüz O., Kramers J., Climate on the southern Black Sea coast during the Holocene. Implications from the Sofular Cave record, „Quaternary Science Reviews”, 30 (19-20), 2011, s. 2433-2445.

Guillet S., Corona C., Stoffel M., Khodri M., Lavigne F., Ortega P., Eckert N. i in., Climate response to the Samalas volcanic eruption in 1257 revealed by proxy records, „Nature Geoscience”, 10 (2), 2017 , s. $123-128$.

Haldon J., Elton H., Huebner S.R., Izdebski A., Mordechai L., Newfield T.P., Plagues, climate change, and the end of an empire. A response to Kyle Harper's ", The fate of Rome” (1). Climate, „History Compass”, 16 (12), 2018, e12508.

Haldon J., Elton H., Huebner S.R., Izdebski A., Mordechai L., Newfield T.P., Plagues, climate change, and the end of an empire. A response to Kyle Harper's "The fate of Rome" (2). Plagues and a crisis of empire, „History Compass”, 16 (12), 2018, e12506.

Haldon J., Elton H., Huebner S.R., Izdebski A., Mordechai L., Newfield T.P., Plagues, climate change, and the end of an empire. A response to Kyle Harper's "The fate of Rome" (3). Disease, agency, and collapse, „History Compass”, 16 (12), 2018, e12507.

Harper K., The fate of Rome. Climate, disease, and the end of an empire, Princeton 2017.

Heinrich I., Touchan R., Liñán I.D., Vos H., Helle G., Winter-to-spring temperature dynamics in Turkey derived from tree rings since $A D$ 1125, „Climate Dynamics", 41, 2013, s. 1685-1701.

Izdebski A., Byzantine Miletus. Environmental history of the hinterland, „Archäologischer Anzeiger”, 2, 2016, s. 270-280.

Izdebski A., The economic expansion of the Anatolian countryside in Late Antiquity. The coast versus inland regions, „Late Antique Archaeology”, 10, 2013, s. 343-376.

Izdebski A., Średniowieczni Rzymianie i przyroda. Interdyscyplinarna historia środowiskowa, Kraków 2018.

Izdebski A., Koloch G., Słoczyński T., Exploring Byzantine and Ottoman economic history with the use of palynological data. A quantitative approach, „Jahrbuch der österreichischen Byzantinistik”, 65, 2015, s. 67-110.

Izdebski A., Mordechai L., White S., The social burden of resilience. A historical perspective, „Human Ecology”, 46, 2018, s. 291-303.

Izdebski A., Pickett J., Roberts N., Waliszewski T., The environmental, archaeological and historical evidence for regional climatic changes and their societal impacts in the Eastern Mediterranean in Late Antiquity, „Quaternary Science Reviews”, 136, 2016, s. 189-208.

Jones M.D., Roberts C.N., Leng M.J., Türkeş M., A high-resolution late Holocene lake isotope record from Turkey and links to North Atlantic and monsoon climate, „Geology”, 34, 2006, s. 361-364.

Kaplan M., Les hommes et la terre à Byzance du VTe au XIe siècle. Propriété et exploitation du sol, Paris 1992.

Lavigne F., Degeai J.-P., Komorowski J.-C., Guillet S., Robert V., Lahitte P., Oppenheimer C. i in., Source of the great A.D. 1257 mystery eruption unveiled, Samalas volcano, Rinjani Volcanic Complex, Indonesia, „Proceedings of the National Academy of Sciences”, 110 (42), 2013, s. 16742-16747.

Morris R., The powerful and the poor in tenth-century Byzantium. Law and reality, „Past and Present”, 73, 1976, s. 3-27.

Niewöhner P., Aizanoi and Anatolia. Town and countryside in late Late Antiquity, „Millenium. Jahrbuch zu Kultur und Geschichte des ersten Jahrtausends n. Chr.”, 3, 2006, s. 239-253.

Niewöhner P., Urbanism, w: The archaeology of Byzantine Anatolia. From the end of Late Antiquity until the coming of the Turks, ed. P. Niewöhner, Oxford 2017, s. 39-59 (https://www.academia.edu/36208255/ Urbanism, dostęp: 19 listopada 2019).

Oppenheimer C., Orchard A., Stoffel M., Newfield T.P., Guillet S., Corona C., Sigl M., Cosmo N.D., Büntgen U., The Eldgjá eruption. Timing, long-range impacts and influence on the Christianisation of Iceland, „Climatic Change”, 147 (3-4), 2018, s. 369-381.

Özel O., The collapse of rural order in Ottoman Anatolia. Amasya 1576-1643, Leiden 2016 (Ottoman Empire and its Heritage, 61).

Popkiewicz M., Kardaś A., Malinowski S., Nauka o klimacie, Katowice 2018.

Sadori L., Giraudi C., Masi A., Magny M., Ortu E., Zanchetta G., Izdebski A., Climate, environment and society in southern Italy during the last 2000 years. A review of the environmental, historical and archaeological evidence, „Quaternary Science Reviews”, 136, 2016, s. 173-188.

Scott J.C., Against the grain. A deep history of the earliest states, New Haven 2017.

Svoronos N., Les Novelles des empereurs macedoniens concernant la terre et les stratiotes, Athènes 1994.

Thonemann P., The Maeander Valley. A historical geography from antiquity to Byzantium, Cambridge 2011.

Touchan R., Akkemik Ü., Hughes M.K., Erkan N., May-June precipitation reconstruction of southwestern Anatolia, Turkey during the last 900 years from tree rings, „Quaternary Research”, 68 (2), 2007, s. 196-202.

Towns and their territories between late antiquity and the early Middle Ages, ed. G.P. Brogiolo, N. Gauthier, 
N. Christie, Leiden 2000 (Transformation of the Roman World, 9).

Varinlioğlu G., Trade, craft and agricultural production in town and countryside in southeastern Isauria, w: Archaeology and the cities of Asia Minor in Late Antiquity, ed. O. Dally, C. Ratté, Ann Arbor, Mich 2011 (Kelsey Museum Publication, 6), s. 151-171.

Wahlgren S., Symeonis Magistri et Logothetae Chronicon, Berlin 2006.

Weiberg E., Unkel I., Kouli K., Holmgren K., Avramidis P., Bonnier A., Dibble F. i in., The socio-environmental history of the Peloponnese during the Holo- cene. Towards an integrated understanding of the past, "Quaternary Science Reviews”, 136, 2016, s. 40-65.

White S., The climate of rebellion in the early modern Ottoman Empire, Cambridge 2011.

Xoplaki E., Fleitmann D., Luterbacher J., Wagner S., Haldon J.F., Zorita E., Telelis I., Toreti A., Izdebski A., The Medieval climate anomaly and Byzantium. A review of the evidence on climatic fluctuations, economic performance and societal change, „Quaternary Science Reviews", 136, 2016, s. 229-252.

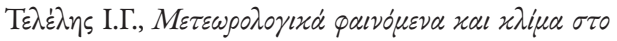

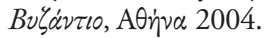

\section{Climatic Changes as Catalysts of Societal Changes in Past Societies}

\section{Summary}

Research goals of the article. The purpose of the article is to look at the role of climate fluctuations as a catalyst for societal change in pre-modern societies. It is also to consider social adaptation to climate change as an ambivalent process that, on the one hand, allows specific political and socio-economic systems to survive or even strengthen, on the other hand is associated with a change in the mutual balance of individual social groups. Main theses. Climate fluctuations cannot be studied in isolation from the dynamics of social, economic, political, and ecological processes that occur constantly in a society and its natural environment. Climate fluctuations can be understood as external interference in the socio-natural system that changes the mutual balance of its elements (ecosystems, social groups, institutions) and requires their adaptation. In the adaptation process, there is a change in the relationship of power and in the access to resources within the system. In this way, the climate becomes a catalyst for societal change, but it is not its main cause (it becomes an additional factor contributing to the ongoing socio-ecological processes), nor is it the main determinant of the direction of change.

Results. The following phenomena have been considered in the article:

- change in the socio-economic importance of cities and villages in the late antiquity in the context of fluctuations in hydro-climatic variables in this period in the Eastern Mediterranean; - subsidence crises, harsh winters and increased control of the elite over the rural strata in the tenth-century Byzantium;

- the role of temporary cooling in the process of Islamization of Anatolia in the thirteenth century. Conclusions. The discussed cases show how important it is to treat the climate - a physical force - as an actor operating within a complex network of socio-natural relationships.

dr Adam Izdebski - historyk i bizantynista, adiunkt w Instytucie Historii Uniwersytetu Jagiellońskiego oraz kierownik niezależnej grupy badawczej zajmującej się historią środowiskową w Instytucie Maxa Plancka Historii Ludzkości w Jenie. Interesuje się społeczną historią krajobrazów w świecie rzymskim i bizantyjskim oraz historią klimatu, a także szerzej kulturą późnego antyku i Bizancjum. W swoich pracach badawczych kładzie nacisk na równoległe wykorzystywanie informacji pochodzących z nauk przyrodniczych i historycznych. Autor m.in. książki Średniowieczni Rzymianie i przyroda. Interdyscyplinarna historia środowiskowa (Warszawa 2013) oraz redaktor i współautor (wspólnie z Rafałem Szmytką) Ekobiografii Krakowa (Kraków 2018, wyd. ang.: Pittsburgh 2020) (adam.izdebski@uj.edu.pl) 
Adam Izdebski, PhD - Historian and Byzantinist, assistant professor at the Institute of History of the Jagiellonian University and the leader of an independent research group working on environmental history at the Max Planck Institute for the Science Human History in Jena. He is interested in the social history of landscapes in the Roman and Byzantine world and climate history, as well as in the culture of Late Antiquity and Byzantium. In his research work, he emphasises the parallel use of evidence coming from the natural and historical sciences. The author of Średniowieczni Rzymianie i przyroda. Interdyscyplinarna historia środowiskowa (Warszawa, 2013) and co-author and editor of the Ekobiografia Krakowa (Kraków 2018, English edition: Ecobiography of Kraków, Pittsburgh 2020)

(adam.izdebski@uj.edu.pl) 